\title{
Public Debt Stock, Education-Centric Human Capital and Economic Growth in Nepal
}

\author{
Madhav Prasad Dahal*
}

\begin{abstract}
Government borrows from domestic and foreign sources to finance its budget deficit. There are theories and empirical evidence that suggests negative effect of government debt on economic growth. By applying the autoregressive distributive lag $(A R D L)$ approach to cointegration on time series data of Nepal spanning over 1975-2014, this study finds positive and statistically significant effect of total public debt on the GDP of the country. This result contradicts majority of the existing empirical literature. For the positive result we resort to Keynesian view on the effect of public debt in the economy. The total debt-to-GDP ratio of Nepal shows a declining trend. This should have some policy considerations in the conduct of fiscal policy in Nepal. The contribution of education-centric human capital on GDP is found positive as predicted by theory.
\end{abstract}

Key words: government debt stock, gross fixed capital formation, education, GDP, ARDL, Nepal

\section{BACKGROUND}

Why do governments borrow? Can't they balance their budget? There are differences in answers that macroeconomists offer to these questions. Government in every country spends its revenue on a number of things like social welfare, capital expenditure (e.g., investments in buildings schools and hospitals, roads, public facilities etc,), national defence, compensation to government employees among others. To finance all such expenditures, government relies on taxes and other revenues. But to increase tax to finance increased expenses on several activities is not a popular way; people do not like to pay more taxes. In countries with low level of per capita income and hence with low levels of taxpaying capacity of the people, government has limitations in increasing taxes. Realized tax revenue collection of the government would be less than predicted. However government cannot stop its overall spending due to its growing role and responsibility in the economy. During time of recession revenue collection falls but government has to increase spending to stimulate the economy, increase unemployment allowances and continue spending on social security. For that reason in an era of expanding government activities, it is hard for the government to downsize its spending volume and exactly balance its budget, or increase tax every

${ }^{*}$ Mr. Dahal is Associate Professor of Economics at Patan Multiple Campus, Tribhuvan University, Nepal 
time to finance its rising spending. Therefore borrowing would be a healthy option to the government to finance its growing expenses as long as it can repay its debts.

Like many governments of the world, running a deficit budget and financing it by borrowing has been a feature of Nepal government's budgetary operation. Government of Nepal borrows from both foreign and domestic sources to finance its deficit-spending. Internally it borrows mainly from the banking sector and externally it borrows from both bilateral and multilateral sources. Due to continued borrowing the stock of outstanding debt of the government has become large in volume. There is fear that the large volume of outstanding debt of the government has threat to the economy. Therefore the objective of this paper is to analyze the trend of government debt and debt-to-GDP ratio and search whether the outstanding debt has any growth retarding effect in Nepal.

\section{A TRIP ON THEORETICAL AND EMPIRICAL INFORMATION}

There are theoretical grounds and empirical evidence on the effect of government/ public debt in the economy both in the short-and long-run. A survey of literature on several issues linked to the impact of government debt in the economy is found in Elmendorf and Mankiw (1999).Theoretically there are three strands on the effect of public debt on economic growth: the Keynesian approach, the neoclassical approach, and Ricardian approach.

The Keynesian approach is that expansionary fiscal policy resulting in rising budget deficit and public debt increases aggregate demand and output in the short-run through budgetary multiplier (Haavelmo, 1945; Baumol \& Maurice, 1955). Furthermore debt may also lead to public investments (for example, infrastructural developments) which may enlarge the capacity to supply aggregate output.

Contrary to the Keynesian argument the neoclassical theory (Diamond, 1965; Modigliani, 1961; Saint-Paul, 1992) makes the case that increasing public debt is disadvantageous because an expansive fiscal policy increases current consumption, which in turn leads to the decline of the saving rate. Consequently the level of interest rate rises which in turn will lead to a decline in private sector's investments and a slowdown of growth. Thus there is crowd out of investment and capital and reduction in output in the long-run.

In contrast to the above two opinions, the Ricardian equivalence proposition indicates that government debt does not affect economic growth (Barro, 1989). The hypothesis means that at the time when budget deficit is growing due to fiscal stimulus government 
debt speeds up and market players prepare for future period of austerity measures, tax rises, and consequently they shift their focus from consumption and investment to increasing savings, which neutralizes the impact of the demand-inducing fiscal policy.

There are diverse channels through which government debt accumulation adversely affects medium-run to long-run growth. For example, study of Gale and Orzag (2003) and Baldacci and Kumar (2010) reveal that high public debt can adversely affect capital accumulation and growth by means of higher long-term interest rates; Barro (1979) and Dotsey (1994) point out that high public debt affects growth through higher future distortionary taxation; Sargent and Wallace (1981), Barro (1995) and Cochrane (2011) point out that adverse effect of government debt on growth works through inflation channel. Analysis of Burnside, Eichenbaum and Rebelo (2001) and Hemming, Kell and Schimmelpfennig (2003) further add that large debt of government, by sparking off a banking or currency crisis, can magnify several adverse effect of public debt on growth. Some authors have also pointed out that high public debt would possibly restrict the power of countercyclical fiscal policies which may result in higher volatility and further lower growth. For example Woo (2009) investigates the effects of procyclicality and volatility of fiscal policy on growth.

Of late Reinhart and Rogoff (2010) studied economic growth and inflation at different levels of government and external debt. Their analysis is based on new data on fortyfour countries spanning the period of 1790-2009. The study mainly found that (i) the relationship between government debt and real GDP growth is weak for debt-to-GDP ratios below a threshold of 90 percent and for levels above 90 percent the median growth rates fall by one percent and the average growth rates considerably more, and finally (ii) the threshold for public debt is similar in advanced and emerging economies. Kumar and Woo (2010) in their study based on a panel of advanced and emerging economies also found a similar change in the behaviour of GDP growth in relation to the debt ratio. Their empirical results suggested an inverse relationship between initial debt and subsequent growth controlling for other determinants of growth. This study found that on the average a 10 percentage point increase in the initial debt-toGDP ratio was associated with a slowdown in annual real per capita GDP growth and of around 0.2 percentage point per year, with the impact being somewhat smaller in advanced economies.

The study of Cordella, Ricci and Ruiz-Arranz (2010) found a negative relationship between external public debt and growth in developing countries with intermediate levels of debt but no significant relationship between debt and growth in developing countries with very low or very high levels of debt. They also found that in countries 
with bad policies debt may not matter at all. In a panel of around 100 developing countries, Pattillo, Poirson and Ricci (2011) found a non-linear relationship between the net present value of external debt and economic growth. Their results suggested that the marginal effect of debt becomes negative when the net present value of debt reaches 20 percent of GDP. Presbitero (2012) uses total public debt and finds no significant relationship between public debt and growth in developing countries with bad policies and institutions. Panizza and Presbitero (2013) provide a detailed survey of literature on government debt and economic growth and conclude that although there is evidence of negative correlation of public debt with economic growth, there is no study that can make a strong case for a causal relationship going from debt to growth. They also showed that the presence of debt thresholds and in general, of a nonmonotonic relationship between debt and growth is not robust to small changes in data coverage and empirical techniques.

Thus majority of the existing empirical literature reports a negative association between government debt and GDP. Does the negative relation also hold in the context of Nepal? There has not been sufficient empirical analysis in the context of Nepal to quantify the impact of total outstanding debt of government on the GDP of the country by covering a longer time period as of this study (sample period 1975-2014) by testing the time series property of the variables considered. To the best of the knowledge of this author the impact of public debt stock combined with education-centric human capital on the GDP of Nepal has not been made. This study fills this gap by applying the ARDL method of cointegration by incorporating debt stock data with gross fixed capital formation and education-centric human capital to analyze their impact on the GDP of Nepal. This work should be an interesting stuff to the intellectual community and policy practioners.

\section{RESEARCH STRATEGIES}

The strategy of this paper to quantify the relationship of Nepal Government's debt stock with the GDP of the country starts with a production function. We specify a Cobb-Douglas production function characterized by constant returns to scale in four arguments viz, gross fixed capital formation (GFCF), government's total debt stock (TD), a measure of education-centric human capital (HC), and labour force (L).

$$
\operatorname{GDP}_{t}=\mathrm{A}_{\mathrm{t}} \mathrm{GFCF}_{\mathrm{t}}^{\alpha} \mathrm{TD}_{\mathrm{t}}^{\beta} \mathrm{HC}_{\mathrm{t}}^{\lambda} \mathrm{L}_{\mathrm{t}}^{1-\alpha-\beta-\lambda}
$$

where GDP is gross domestic product measured in millions of local currency, is A scale factor (overall production efficiency parameter), and $t$ is an index of time. 
The variables GDP, GFCF, and TD are measured in current prices of millions of NRs (Nepalese rupees).Labour force (L) is proxied by the projected population of the age group 15-64 years. Education-centric human capital (HC) is proxied by total number of students enrolled in school level education of Nepal (from primary level to secondary level).

Government's total debt stock (TD) is the main variable of interest of this study. We include the debt variable (TD) in the production function drawing upon neoclassical production theory and studies by Johnston (1969), Levhari and Patinkin (1968), and Nadiri (1969) who suggest that money is one of the input factors of the real GDP growth rate. GFCF is a proxy measure of capital, a conventional factor of production.

Education centric-human capital is incorporated in the production function following new (endogenous) growth theory innovated by Lucas (1988) and Romer (1990a). In particular the theoretical literature on economic growth pinpoints the following channels through which education-centric human capital may affect economic growth performance of nations: (i) Human capital works as a factor of input in production activities and shift growth towards a higher equilibrium level of output (Lucas, 1988; Mankiw, Romer, \& Weil, 1992; Uzawa, 1965).(ii) Accumulation of education-centric human capital can increase the innovative capacity of the economy and the new knowledge on new technologies, products, and processes promotes endogenous growth (Romer, 1990b).(iii) Education can facilitate the diffusion and transmission of knowledgeneeded tounderstand and processnew information (technological diffusion) and to successfully implement new technologies created by others (technological catch-up), which again promotes economic growth (Benhabib \& Spiegel, 1994; Nelson \& Phelps, 1966; Romer, 1986).(iv)Accumulation of human capital generates positive externalities, the members and fellow workers become more productive which leads to endogenous growth (Lucas, 1988). (v) Human capital accumulation may affect physical capital investment and thus create an indirect effect on growth performance (Benhabib \& Spiegel, 1994).

For ease in operation we drop the time subscript and divide both sides of equation (1) by $\mathrm{L}$ to express the production function in per capita term as

$$
\frac{\mathrm{GDP}}{\mathrm{L}}=\mathrm{A}\left(\frac{\mathrm{GFCF}}{\mathrm{L}}\right)^{\alpha}\left(\frac{\mathrm{TD}}{\mathrm{L}}\right)^{\beta}\left(\frac{\mathrm{HC}}{\mathrm{L}}\right)^{\lambda}
$$

Taking natural logarithm on both sides of equation (2)

$$
\ln \mathrm{Y}=\ln \mathrm{A}+\alpha \ln \mathrm{GFCF}+\beta \ln \mathrm{TD}+\lambda \ln \mathrm{H}
$$


Where $\ln Y=$ Natural logarithm of GDP per worker, $\operatorname{lnGFCF=Natural~logarithm~of~}$ GFCF per worker, $\operatorname{lnTD}=$ Natural logarithm of total debt per worker, $\ln \mathrm{H}=$ Natural logarithm of per worker education-centric human capital. The term ' $\ln A^{\prime}$ is treated as an intercept in the regression estimation.

\section{Data Sources}

The sample period of this study is 1975-2014. The required data are collected from Economic Survey(several issues) published by Ministry of Finance, Government of Nepal, and A Handbook of Government Finance Statistics Vol.III published by Nepal Rastra Bank (the Central Bank of Nepal) (2010).

\section{Unit Root Test of the Time Series}

The autoregressive distributed lag(ARDL) approach also known as bounds testing approach to cointegration, originally developed by Pesaran and Shin (1997) and later extended by Pesaran, Shin and Smith (2001), is based on the assumption that time series under investigation are integrated of order zero, I (0), or integrated of order one, I (1) or mutually cointegrated. Therefore, before applying this method of cointegration, we have to test for the order of integration of all variables using the unit root tests to be sure that none of the variables are integrated of order 2 or beyond (Ouattara, 2004) because in the presence of I (2) variables the computed F-statistic provided by Pesaran, Shin and Smith (2001) are not valid and we cannot interpret the given F-statistics.

We apply the augmented Dickey-Fuller (ADF) test (Dickey \& Fuller, 1979, 1981) to identify the stationarity or non-stationarity of the time series under investigation. The $\mathrm{ADF}$ test for a unit root up to the pth lag, $\mathrm{AR}(\mathrm{p})$, tests the null hypothesis $\mathrm{H}_{0}: \delta=0$ (non-stationary/has unit root) against the one-sided alternative $\mathrm{H}_{1}: \delta<0$ (stationary/ no unit root) estimating regression equation (4) by OLS method:

$$
\Delta \mathrm{Y}_{\mathrm{t}}=\beta_{0}+\phi \mathrm{T}+\delta \mathrm{Y}_{\mathrm{t}-1}+\gamma_{1} \Delta \mathrm{Y}_{\mathrm{t}-1}+\gamma_{2} \Delta \mathrm{Y}_{\mathrm{t}-2}+\ldots+\gamma_{\mathrm{p}} \Delta \mathrm{Y}_{\mathrm{t}-\mathrm{p}}+\mathrm{u}_{\mathrm{t}}
$$

where $\phi$ is an unknown coefficient of the variable time index ' $T$ ', and the ADF statistic is the OLS t-statistic(tau-statistic) testing $\delta=\sigma-1=0$ in equation (4).This equation tests the alternative hypothesis that $\mathrm{Y}_{\mathrm{t}}$ is stationary around a deterministic linear time trend.

Practically we reject the null hypothesis of non-stationarity (i.e., $\delta=0$ ) if $\delta$ is adequately statistically negative (i.e., for rejection of the null hypothesis the computed tau $(\tau)$ statistic must be more negative than the critical values and must be statistically significant. The lag length $\mathrm{p}$ in the autoregression can be determined by using the 
Schwarz Information Criteria (SIC) also called Swartz Bayesian Criteria (SBC) or Akaike Information Criteria (AIC) or Hanna-Quinn Criteria (HQC). The rule is to choose the lag length by minimizing an 'information criteria' among the possible choices (Stock \& Watson, 2006). Values associated to these information criterions are automated in different econometric Softwares. In this study we use the SIC (SBC) criteria to select lag in the ADF unit root test.

\section{Cointegration Test: The ARDL Approach}

Even if there are different approaches of testing cointegration (e.g., Engle \& Granger, 1987 ; Stock \& Watson, 1988 ; Johansen,1988, 1991; Johansen \& Juselius , 1990), we employ the bounds testing approach to cointegration within an autoregressive distributed lag (ARDL) framework developed by Pesaran and Shin (1997), and Pesaran, Shin and Smith (2001). An ARDL model refers to a model with lags of both the dependent and explanatory variables. Because dynamic effects necessarily occur over time, the econometric model used to estimate dymanic causal effects needs to incorporate lags.To do so the dependent varaible can be expressed as a distributed lag of current and p past values of the explanatory variables (Stock \& Watson, 2006).

The ARDL method of cointegration has certain econometric advantages over alternative cointegration procedures. Firstly, this technique is robust for cointegration analysis with small sample study (Narayan \& Smith, 2005). The bi-variate cointegration test introduced by Engle and Granger (1987) and the multivariate cointegration technique proposed by Stock and Watson (1988), Johansen $(1988,1991)$ and Johansen and Juselius (1990) may be applicable for large sample size and are not reliable for small sample sizes (as in the case of this study). The second benefit is that it can be applied irrespective of whether the regressors are I (0), I (1), or even integrated of the same order or mutually cointegrated. This is well known that the conventionally used cointegration approaches, for example Engle and Granger (1987), Johansen(1988), and Johansen and Juselius (1990), are applicable for nonstationary series with same order of integration, I(1). The third advantage is that the unrestricted error correction model (UECM) is likely to have better statistical properties than the two-step EngleGranger (E-G) method (Narayan \& Smith, 2005) because unlike the E-G method, the UECM does not push the short run dynamics into the residual terms (Banerjee, Dolado, Galbraith \& Hendry, 1993; Banerjee, Dolado \& Mestre, 1998; Pattichis, 1999). Additionally this approach allows to derive a dynamic error-correction model from ARDL through simple linear transformation (Banerjee, Dolado, Galbraith \& Hendry, 1993) that integrates the short-run dynamics with long-run equilibrium without losing long-run information and thus allows to draw inference for long run estimates that is not available in other alternative cointegration procedures (Sezgin \& Yildirim, 
2002). The ARDL approach estimates both the long-run and short-run relationships simultaneously.

The fourth plus point of the ARDL bounds test approach is that it is capable of distinguishing dependent and explanatory variables and thereby helps avoiding the problems of endogeneity (Rehman \& Afzal, 2003). Fifthly, the ARDL approach involves just a single-equation set-up, making it simple to implement and interpret. Sixthly, the ARDL approach offers more choices regarding the inclusion of number of endogenous and exogenous variables, if any, the treatment of deterministic elements, as well as the order of vector autoregression (VAR), and the optimal number of lags to be used which are limited in Johansen's method (Pahlavani, Wilson \& Worthington, 2005; Pesaran \& Smith, 1998). Finally, the ARDL bounds testing procedure generally provides unbiased estimates of the long-run model and valid t-statistics because they avoid the problems that may arise due to serial correlation and endogeneity (Harris \& Sollis, 2003; Odhiambo, 2009).

\section{Steps in the ARDL Approach}

The ARDL bounds test method of cointegration involves two stages. The first stage requires the test of the existence of a long-run relationship between the variables under research by means of the computation of the F-statistic for testing the significance of the lagged levels of the variables in the error correction form of the underlying ARDL model. The F-test depends upon: (i) whether variables included in the ARDL model are I (0) or I (1), (ii) the number of regressors (k), and (iii) whether the ARDL model contains an intercept and/or intercept and trend. If the computed F-statistics is greater than the proper upper bound critical values, the null hypothesis of no cointegration is rejected in favour of cointegration. If the computed F-statistics falls below the lower bound critical values, the null of no cointegration cannot be rejected in which case there is absence of cointegration. If the computed F-statistic falls within the critical value band (i.e., if it falls within the upper and lower bounds), the result is inconclusive. Under the inconclusive situation, following Kremers, Ericsson and Dolado (1992) and Banerjee, Dolado and Mestre (1998), the error correction term (ECT) will be a useful way of confirming cointegration (Verma, 2007). Of course we have to rely on the significance of the error correction term as a useful way for establishing cointegration.

The second stage test is dependent upon the result of the first stage F-test. If the first stage test suggests the existence of cointegration among the variables, then the second stage involves additional two-step procedure: an estimation of the long run and short run parameters using the related ARDL and error correction models (ECMs).In doing so in the first step the orders of the lags in the ARDL model are selected. The ARDL model is computationally expensive (Laurenceson \& Chai, 2003), requiring to estimate 
$(p+1)^{k}$ number of regression equations in order to obtain the optimal lag length for each variable, where $\mathrm{p}$ is the maximum number of $\operatorname{lag}(\mathrm{s})$ to be used and $\mathrm{k}$ is the number of variables (regressors) in the equation (Liang \& Cao, 2007).

\section{Lag Length Selection in the ARDL Model}

ARDL test results often depend significantly on the number of lagged differences included in the regression equation. If random lag values are specified, the resulting statistical inferences are likely to be invalidated. In response to this problem one of the procedures proposed for determining the proper length of the distributed lag is the use of selection criteria. We can use the Akaike Information Criterion (AIC), the Schwartz Bayesian Criteria (SBC) or Hannan-Quinn Criterion (HQC) to choose the lag order to obtain a parsimonious ARDL model. Though the theoretical limitation of the AIC is that in large samples it will overestimate $\mathrm{p}$ with nonzero probability, it is widely used in practice (Stock \& Watson, 2006). The BIC may possibly produce a model with too few lags and hence the AIC provides a reasonable alternative (Stock \& Watson, 2006). The SIC or the BIC is known as selecting the parsimonious model by selecting the smallest possible lag length whereas AIC is known for selecting the maximum relevant lag length (Shrestha, 2005). Regarding the choice of the model, the specification with smaller AIC or SIC/SBC are better (Studenmund, 2000). In our study we use the BIC (SBC) to select the optimum lag in the ARDL model.

Economic growth studies that apply the ARDL method of cointegration have used a lag order of one or two. For example, Seetanah (2008) used one lag while Laurenceson and Chai (2003) and Narayan and Smith (2005) used two lags. Drawing upon the previous literature we use a lag order of two in the ARDL equation. The choice of the order of ARDL in this study is also influenced by the limited capacity of the demo version of Microfit 5 in the estimation.

Following Pesaran, Shin and Smith (2001), an ARDL representation of equation (3) is specified as:

$$
\begin{aligned}
\Delta \ln \mathrm{Y}_{\mathrm{t}}=\mu+ & \sum_{\mathrm{i}=0}^{\mathrm{m}} \eta_{\mathrm{i}} \Delta \ln \mathrm{Y}_{\mathrm{t}-\mathrm{i}}+\sum_{\mathrm{i}=0}^{\mathrm{n}} \omega_{\mathrm{i}} \Delta \ln \mathrm{GFCF}_{\mathrm{t}-\mathrm{i}}+\sum_{\mathrm{i}=0}^{\mathrm{p}} \phi_{\mathrm{i}} \Delta \ln \mathrm{TD}_{\mathrm{t}-\mathrm{i}}+\sum_{\mathrm{i}=0}^{\mathrm{q}} \pi_{\mathrm{i}} \Delta \ln \mathrm{H}_{\mathrm{t}-\mathrm{i}} \\
& +\theta_{1} \ln \mathrm{Y}_{\mathrm{t}-1}+\theta_{2} \ln \mathrm{GFCF}_{\mathrm{t}-1}+\theta_{3} \ln \mathrm{TD}_{\mathrm{t}-1}+\theta_{4} \ln \mathrm{H}_{\mathrm{t}-1}+\mathrm{u}_{\mathrm{t}}
\end{aligned}
$$

where $\Delta$ denotes first difference operator, $\mu$ is the intercept term, and $\mathrm{u}_{\mathrm{t}}$ is the usual white noise residuals. 
Equation (5) differs from standard distributed lag models in that it includes a linear combination of the lagged level of all variables, normally referred to as an errorcorrection term (Bahamani-Oskooee \& Ardalani, 2006). The ARDL model given in equation (5) integrates the short-run dynamics with the long run equilibrium without losing any information for the long run. From the model estimated in the first step, the long run coefficients are obtained as the coefficients of the one-period lagged explanatory variables (multiplied by a negative sign) divided by the coefficients of the lagged dependent variables (Bardsen, 1989; Akinboade, Ziramba \& Kumo, 2008).Thus in the ARDL specification of (5) the coefficients ' $\theta_{1}$ to $\theta_{4}$ ' represent the long-run relationship whereas the remaining expressions with summation sign (coefficients $\eta_{i}, \omega_{i}, \phi_{i}, \pi_{i}$ ) represent the short-run dynamics of the model. In time series regression models the coefficients of non-lagged explanatory variables indicate the contemporaneous or immediate effect of a unit change in the regressor on the dependent variable. But in autoregressive models involving the time lag(s) among the regressor(s), the coefficient of the regressor(s) implies the effect only after the specified period. Thus in relation to the autoregressive distributed lag model (5) the dynamic causal effect is the sum of sequence of coefficients $\eta_{i}, \omega_{i}, \phi_{i}$, and $\pi_{i}$ of the differenced variables, and the coefficients $\theta_{1}, \theta_{2}, \theta_{3}$, and $\theta_{4}$ of the one period lagged level variables.

If the variables of the production function with ' $\ln Y^{\prime}$ as the dependent variable are found cointegrated in the first step F-test, then the conditional long-run model can be produced from the reduced form solution of equation (5) when the first-differenced variables jointly equal to zero, that is, by setting $\Delta \ln \mathrm{Y}_{\mathrm{t}}=0=\Delta \ln \mathrm{GFCF}_{\mathrm{t}}=\Delta \ln \mathrm{TD}_{\mathrm{t}}=\Delta \ln \mathrm{H}_{\mathrm{t}^{\prime}}$ the cointegration equation is defined as

$$
\theta_{1} \ln \mathrm{Y}_{\mathrm{t}-1}+\theta_{2} \ln \mathrm{GFCF}_{\mathrm{t}-1}+\theta_{3} \ln \mathrm{TD}_{\mathrm{t}-1}+\theta_{4} \ln \mathrm{H}_{\mathrm{t}-1}=0
$$

The bounds test methodology of Pesaran, Shin and Smith (2001) investigates the null hypothesis of no cointegration through a joint significance test of the lagged levels of variables $\ln Y_{t-1}, \ln \mathrm{GFCF}_{\mathrm{t}-1}, \ln \mathrm{TD}_{\mathrm{t}-1}$ and $\ln \mathrm{H}_{\mathrm{t}-1}$ based on the familiar F-statistics under which the null hypothesis $H_{0}: \theta_{1}=\theta_{2}=\theta_{3}=\theta_{4}=0$ (no cointegration) is tested against the alternative hypothesis $H_{1}: \theta_{1} \neq 0, \theta_{2} \neq 0, \theta_{3} \neq 0, \theta_{4} \neq 0$ (cointegration). Thus following Pesaran et al. (2001), cointegration can be expected if the longrun coefficients of all lagged level variables are jointly significant (i.e., values of $\theta_{i} \mathrm{~s}>0$, for $\left.\mathrm{i}=1, \ldots, 4\right)$.

If variables of a model are cointegrated, there exists an error correction representation. The advent of Granger's representation theorem (Engle \& Granger, 1987) has immensely increased the use of error-correction model in applied time series econometrics. In 
the ARDL approach to cointegration the lagged error correction term $\left(\mathrm{ECM}_{\mathrm{t}-1}\right)$ is generated out of the long-run coefficients to replace linear combination of lagged variables, and the model is re-estimated at the optimum lags selected by using model selection criterion (Bahamani-Oskooee \& Ardalani, 2006). Hence the short-run error correction version of model (5) is specified as:

$$
\Delta \ln \mathrm{Y}_{\mathrm{t}}=\mu_{1}+\sum_{\mathrm{i}=0}^{\mathrm{m}} \eta_{\mathrm{i}} \Delta \ln \mathrm{Y}_{\mathrm{t}-\mathrm{i}}+\sum_{\mathrm{i}=0}^{\mathrm{n}} \omega_{\mathrm{i}} \Delta \ln \mathrm{GFCF}_{\mathrm{t}-\mathrm{i}}+\sum_{\mathrm{i}=0}^{\mathrm{p}} \phi_{\mathrm{i}} \Delta \ln \mathrm{TD}_{\mathrm{t}-\mathrm{i}}+\sum_{\mathrm{i}=0}^{\mathrm{q}} \pi_{\mathrm{i}} \Delta \ln \mathrm{H}_{\mathrm{t}-\mathrm{i}}+\xi \mathrm{ECM}_{\mathrm{t}-1}
$$

In equation (7) ECM is the error correction mechanism term obtained as residual from the estimation of the long run cointegrating equation (3); $\eta_{i}, \omega_{i}, \phi_{i}$, and $\pi_{i}$ are the short-run dynamic coefficients of the model's convergence to equilibrium, and $\xi$ is the speed of adjustment from short run to long run. The error correction mechanism term is thus defined as:

$$
\mathrm{ECM}_{\mathrm{t}}=\ln \mathrm{Y}_{\mathrm{t}}-\gamma_{1} \ln \mathrm{GFCF}_{\mathrm{t}}-\gamma_{2} \ln \mathrm{TD}_{\mathrm{t}}-\gamma_{3} \ln \mathrm{H}_{\mathrm{t}}
$$

where $\gamma_{1}=-\left(\frac{\theta_{2}}{\theta_{1}}\right), \gamma_{2}=-\left(\frac{\theta_{3}}{\theta_{1}}\right), \gamma_{3}=-\left(\frac{\theta_{4}}{\theta_{1}}\right)$ are the ordinary least square (OLS) estimators obtained from equation (5).

The error correction term (ECM) among a set of cointegrated series implies that changes in the response variable are a functions of both the levels of disequilibrium in the cointegrating relationship (represented by the ECM) and the changes in other explanatory variables. The coefficient ' $\xi$ ' of the error correction term in equation (7) is expected to be less than zero $(\xi<0)$ and statistically significant to confirm the existence of cointegrating relation. Banerjee, Dolado and Mestre (1998) note that significant lagged error term with negative sign is the way to prove that established long run relationship is stable. The larger the size of the negative coefficient of the error correction term, the greater is the speed of adjustment from short run to long run.

\section{RESULT AND DISCUSSION}

The analysis proceeds first by making an overview of the evolution of Nepal government's debt stock and total Debt-to-GDP ratio.

\section{Evolution of Government's Debt in Nepal}

The trend of the evolution of the debt stock of the government of Nepal over the period of 1975-2014 is portrayed in Figure 1.These data give some sense of the history of government debt in Nepal. 


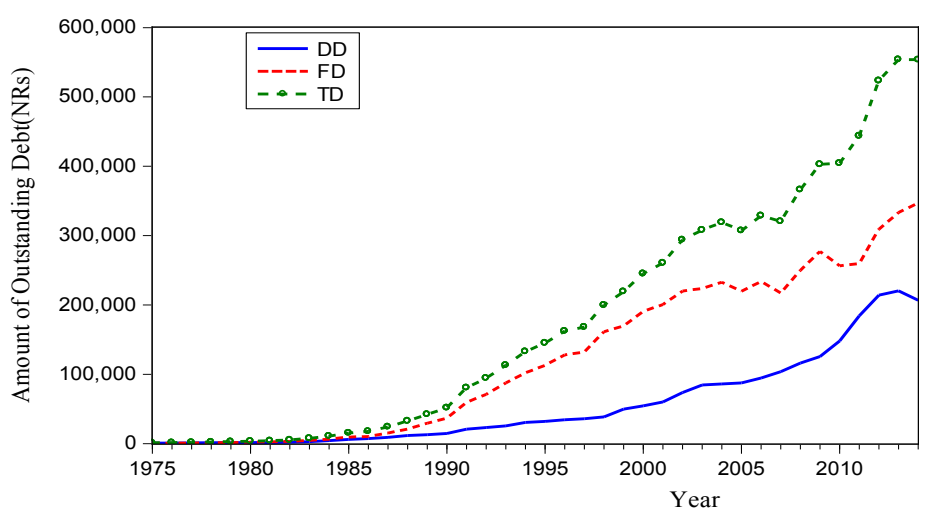

Figure 1: Progression of Nepal's Outstanding Debt

The accumulation of domestic debt (DD), foreign debt (FD) and total debt (TD) has increased over the period of this study. Obviously the stock of foreign debt exceeds the stock of domestic debt.

\section{Debt-to-GDP Ratio}

The ratio of a country's government debt-to-GDP indicates a country's ability to pay back its debt. The ratio of domestic debt to GDP (DD-to-GDP), foreign debt to GDP (FD-to-GDP) and total debt to GDP (TD-to-GDP) is given in Table 1.

Table 1: Public Debt-to-GDP in Ratio in Nepal

\begin{tabular}{lccc|cccc}
\hline Year & DD-to-GDP & FD-to-GDP & TD-to-GDP & Year & DD-to-GDP & FD-to-GDP & TD-to-GDP \\
\hline 1975 & 3.61 & 2.08 & 5.69 & 1995 & 14.63 & 51.56 & 66.18 \\
1976 & 4.24 & 2.74 & 6.98 & 1996 & 13.76 & 51.44 & 65.20 \\
1977 & 5.83 & 3.64 & 9.48 & 1997 & 12.79 & 47.09 & 59.88 \\
1978 & 6.18 & 4.93 & 11.11 & 1998 & 12.77 & 53.59 & 66.35 \\
1979 & 6.26 & 5.95 & 12.20 & 1999 & 14.52 & 49.55 & 64.07 \\
1980 & 6.41 & 7.74 & 14.15 & 2000 & 14.32 & 50.25 & 64.57 \\
1981 & 5.27 & 8.98 & 14.24 & 2001 & 13.60 & 45.39 & 58.99 \\
1982 & 6.11 & 10.25 & 16.37 & 2002 & 16.02 & 47.91 & 63.94 \\
1983 & 8.49 & 13.95 & 22.44 & 2003 & 17.20 & 45.39 & 62.59 \\
1984 & 11.04 & 16.09 & 27.13 & 2004 & 16.05 & 43.37 & 59.42 \\
1985 & 12.95 & 19.75 & 32.70 & 2005 & 14.86 & 37.26 & 52.12 \\
1986 & 12.90 & 18.53 & 31.44 & 2006 & 14.48 & 35.77 & 50.25 \\
1987 & 14.09 & 23.76 & 37.84 & 2007 & 14.26 & 29.76 & 44.02 \\
1988 & 15.13 & 27.08 & 42.21 & 2008 & 14.23 & 30.65 & 44.87 \\
1989 & 14.44 & 32.73 & 47.17 & 2009 & 12.72 & 28.03 & 40.75 \\
1990 & 14.19 & 35.59 & 49.77 & 2010 & 12.41 & 21.48 & 33.90 \\
1991 & 17.33 & 49.44 & 66.76 & 2011 & 13.48 & 18.99 & 32.46 \\
1992 & 15.54 & 47.44 & 62.99 & 2012 & 14.01 & 20.25 & 34.26 \\
1993 & 14.85 & 50.98 & 65.83 & 2013 & 13.00 & 19.67 & 32.67 \\
1994 & 15.37 & 51.17 & 66.54 & 2014 & 10.65 & 17.86 & 28.51 \\
1995 & 14.63 & 51.56 & 66.18 & & & & \\
\hline
\end{tabular}

Source: Author's computation from the data available in the publications of Nepal Rastra Bank (the Central bank of Nepal), and Ministry of Finance, Government of Nepal. 
The figures given in Table 1 reveal that the debt-to-GDP ratio of Nepal is in falling trend. The burden of both domestic and foreign debt as a percent of country's GDP is not alarming. There is room for the government to borrow to finance its budget deficit and enhance the productive capacity of the economy. The money borrowed if spent in expanding transportation facility, hydro or solar power generation, increasing irrigation facility, production of fertilizer for cultivation, capacity building of the labour force and so on would help increase the GDP of the country. The trends of domestic debt to GDP ratio (DDGDP), foreign debt to GDP ratio (FDGDP), and total debt to GDP ratio (TDGDP) is shown in Figure 2.

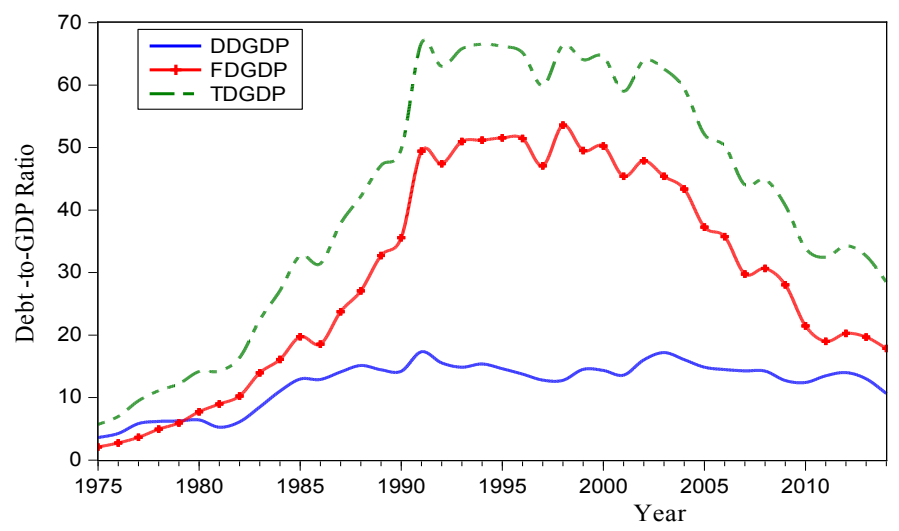

Figure 2: Trends of Nepal's Debt-to-GDP Ratio

Figure 2 shows a clear inverse U-shapes of the foreign debt-to-GDP ratio (FDGDP) and total debt-to-GDP ratio (TDGDP).This raises question on the fiscal policy move: Has there been considerable rise in tax revenue and the government of Nepal reduced the dependence on debt to finance its budget deficit? Or has the government been unable to spend its proposed budgetary amount, and thereby reduced the revenueexpenditure gap and slashed the dependence on public debt from both domestic and foreign sources?

\section{Unit Root Test Result}

The augmented Dickey-Fuller unit root test result (given in Annex-I) indicate that none of the four variables of the model viz per worker GDP( $\operatorname{lnY})$, per worker gross fixed capital formation (lnGFCF), government's total stock of debt (lnTD), and educationcentric human capital per worker(lnH) are integrated of order two; $\ln Y, \operatorname{lnTD}$ and $\ln \mathrm{H}$ are integrated of order one(I 1) and $\operatorname{lnGFCF}$ is integrated of order zero(I 0), that is, lnGFCF has stationary property in level and other variables of the model are stationary in their first difference. Thus we can apply the ARDL approach to cointegration. 


\section{Cointegration Test Result}

The result of the ARDL approach to cointegration on the effect gross fixed capital formation per capita (lnGFCF), total debt (TD) and education-centric human capital per worker $(\ln H)$ on per worker real GDP $(\ln Y)$ is given in Table 2. Test includes intercept $(\mathrm{C})$ in the set of fixed regressors; lag order of the ARDL model is set to two. The adjusted sample period is 1977-2014.

Table 2: Government Debt, Human Capital and GDP : ARDL Bounds Test for Cointegration

Model : $\ln \mathrm{Y}=\mathrm{f}(\ln \mathrm{GFCF}, \ln \mathrm{D}, \ln \mathrm{H}, \mathrm{C})$

ARDL $(1,0,0,1)$ Selected Based on Schwarz Bayesian Criterion

\begin{tabular}{lllll}
\hline & \multicolumn{3}{c}{$95 \%$} & \multicolumn{2}{c}{$90 \%$} \\
\cline { 2 - 5 } Computed F & Lower bound & Upper bound & Lower bound & Upper bound \\
5.0922 & 3.5601 & 4.8365 & 2.9234 & 4.0364 \\
\hline
\end{tabular}

Source: Output of Microfit 5, estimated by the author.

The calculated F-statistic of size 5.0922 is greater than the upper bound critical value at 95 percent confidence level $(5.0922>4.8363)$. Therefore we cannot accept the null hypothesis of no cointegration; we accept the alternative hypothesis that there is a long run cointegrating relationship of the dependent variable real GDP per worker $(\ln Y)$ with the set of main regressors entered in the estimation. The complete result of the first stage of the ARDL approach to cointegration is provided in Annex-II. From Annex-II it is obvious that GDP per worker $(\ln Y)$ and education capital per worker $(\operatorname{lnH})$ enter in the estimation with one lag when the lag selection is on the basis of the Schwarz Bayesian Criterion (SBC).

\section{Long-run Coefficients}

As the first stage F-test indicated the existence of cointegration, in the first step of the second stage of the ARDL approach we estimated the long run coefficients which are given in Table 3.

Table 3 : Estimated Long Run Coefficients Using the ARDL Approach ARDL $(1,0,0,1)$ Selected Based on Schwarz Bayesian Criterion

\begin{tabular}{cccc}
\hline Regressor & Coefficient & Standard Error & t-ratio[Prob.] \\
\hline 1nGFCF & .5595 & .1251 & $4.4759[.000]$ \\
$\operatorname{lnTD}$ & .2265 & .0797 & $2.8410[.008]$ \\
$\ln \mathrm{H}$ & .1778 & .0592 & $3.0052[.005]$ \\
Intercept & 4.1322 & .6411 & $6.4459[.000]$ \\
\hline
\end{tabular}

Source: Output of Microfit 5 estimated by the researcher. 
The result indicates positive impact of gross fixed capital formation (lnGFCF), total debt $(\operatorname{lnTD})$, and education $(\ln \mathrm{H})$ on the real GDP per worker $(\ln \mathrm{Y})$ since the positive coefficients of the explanatory variables are statistically significant at the conventional level of significance. The coefficient size of $\operatorname{lnGFCF}$ is 0.5595 which would mean that the increase in GFCF by one percentage point would on the average add to GDP per worker by about 0.56 percentage points. The statistically significant coefficient of government's total stock of debt per worker (lnTD) is of the size of .2265 which would indicate that a one percentage point increase in debt assist real GDP per capita to grow by about .23 percentage point. One of the purposes of government borrowing is to finance its investment projects which should produce positive effect on GDP of Nepal. The positive and statistically significant coefficient of education-focussed human capital $(\operatorname{lnH})$ is of the magnitude of .1778 which would mean that an increase in school-level enrollment per worker by one percentage point could bring increase in per worker GDP by about .18 percentage point.

\section{The Short-run Dynamics}

The result of the error correction representation of the second step of the second stage of ARDL method to cointegration is given in Table 4. Dependent variable is 'dln Y' with data of the adjusted sample period of 1977-2014.

Table 4 : Error Correction Representation for the Selected ARDL Model ARDL $(1,0,0,1)$ Selected Based on Schwarz Bayesian Criterion

\begin{tabular}{|c|c|c|c|}
\hline Regressor & Coefficient & Standard Error & t-ratio[Prob.] \\
\hline dlnGFCF & .1212 & .0504 & $2.4035[.022]$ \\
\hline $\mathrm{d} \ln \mathrm{TD}$ & .0491 & .0144 & $3.4001[.002]$ \\
\hline $\mathrm{d} \ln \mathrm{H}$ & .1677 & .0486 & $3.4504[.002]$ \\
\hline ECM(-1) & -.2166 & .0525 & $4.1291[.000]$ \\
\hline \multicolumn{4}{|c|}{$\begin{array}{l}\mathrm{d} \ln \mathrm{Y}=\ln Y-\ln Y(-1) ; \mathrm{d} \ln \mathrm{GFCF}=\ln \mathrm{GFCF}-\ln \mathrm{nFCF}(-1) ; \ln \mathrm{TTD}=\ln \mathrm{TD}-\ln \mathrm{lD}(-1) ; \quad \mathrm{d} \ln \mathrm{H}=\ln \mathrm{H}- \\
\ln \mathrm{H}(-1) \\
\mathrm{ECM}=\ln Y-.55952 \ln \mathrm{GFCF}-.22652 \ln \mathrm{TD}-.17781 \ln \mathrm{H}-4.1322\end{array}$} \\
\hline \multicolumn{4}{|c|}{$\mathrm{R}^{2}=.49334 ; \overline{\mathrm{R}}^{2}=.41417 ;$ F-Stat. $(4,33)=7.7896[.000] ; \quad \mathrm{DW}=1.8139$} \\
\hline
\end{tabular}

Source: Output of Microfit 5 estimated by the author.

The negative and statistically significant coefficient of the one period lagged error correction term ' $\mathrm{ECM}_{\mathrm{t}-1}$ ' provides further support to the existence of cointegration of the dependent variable 'real GDP per worker ' with its regressors included in the estimates. The size of $\mathrm{ECM}_{\mathrm{t}-1}$ is -0.2166 which suggests that about 22 percent of the disequilibrium caused by previous period's shocks in the system converges back to the 
long-run equilibrium. The positive and statistically significant short run coefficients related to gross fixed capital formation (dlnGFCF), total debt (dlnTD), and educationcentric human capital $(\mathrm{d} \ln \mathrm{H})$ indicate their respective importance in affecting the real GDP per worker. This suggests that the short run dynamic effect of the selected regressors on GDP per worker is positive.

The fit of the short-run model is good as indicated by the fairly significant F-statistic $[\mathrm{F} .(4,33)=7.7896[.000]$ and the model explains about 41.42 percent of the variation (indicated by R-Bar-Squared] in the dependent variable 'dlnY' (change in real GDP per worker).

Thus our empirical result on the effect of government debt on the GDP of Nepal stand in sharp contrast to the empirical findings of several previous studies which have reported a negative association between government debt and economic growth. To support the positive effect of total debt to GDP we base on the Keynesian proposition. The Keynesian thesis is that easy fiscal policy characterised by rising budget deficit and public debt increases aggregate demand and output in the short-run through budgetary multiplier (Haavelmo, 1945; Baumol \& Maurice, 1955). In addition debt may also lead to public investments (for example, infrastructural developments like roads, hydropower generation, implementation of irrigation projects, etc.) which may enlarge the capacity to supply aggregate output. In least developed country like Nepal the involvement of government in infrastructural capital building is significant. Government every year makes investment in gross capital formation. The data on Nepal's foreign loan disbursement reveal that foreign loan is used in the agriculture, transportation and health as well as education sectors among others. These types of spending definitely help in bringing rise in the level of GDP of the country. There is no doubt that in Nepal government debt is used at least partly to finance productive public capital and an increase in debt would have positive effects up to a certain threshold and beyond then only it would produce negative effect.

\section{Diagnostic Test}

The reliability of the estimated ARDL model $[\ln Y=f(\operatorname{lnGFCF}, \operatorname{lnTD}, \ln H, C)]$ is further investigated through its diagnostic test of serial correlation, functional form, normality and heteroscedasticity of residual variances. The results are given in Table 5. The result contains both the Lagrangian multiplier (LM) and F-test versions of the statistic as automated in Microfit 5. 
Table 5 : Model: $\ln Y=f(\operatorname{lnGFCF}, \operatorname{lnTD}, \ln H, C)$; Sample:1977-2014 ARDL $(1,0,0,1)$ Selected Based on Schwarz Bayesian Criterion

\begin{tabular}{lcc}
\hline Test Statistics & \multicolumn{1}{c}{ LM Version } & F Version \\
\hline A: Serial Correlation & $\chi^{2}{ }_{(1)}=.16921[.681]$ & $\mathrm{F}(1,31)=.13865[.712]$ \\
B: Functional Form & $\chi^{2_{(1)}=.63377[.426]}$ & $\mathrm{F}(1,31)=.52579[.474]$ \\
C: Normality & $\chi^{2}{ }_{(2)}=.29900[.861]$ & Not applicable \\
D: Heteroscedasticity & $\chi^{2}{ }_{(1)}=.18796[.665]$ & $\mathrm{F}(1,36)=.17895[.675]$ \\
\hline
\end{tabular}

Note: A: Lagrange multiplier test of residual serial correlation

B: Ramsey's RESET test using the square of the fitted values

C: Based on a test of skewness and kurtosis of residuals

$\mathrm{D}$ : Based on the regression of squared residuals on squared fitted values

Source: Output of Microfit 5 estimated by the author.

The ARDL model fairly passes all diagnostic tests required for a good regression model. This is indicated by the probability values corresponding to each of the test statistics given within the square brackets which are all more than 0.05 . We further examined the stability of the ARDL cointegration space of the model $[\ln Y=f(\operatorname{lnGFCF}$, $\operatorname{lnTD}, \ln \mathrm{H}, \mathrm{C})$ ] by plotting the cumulative sum of recursive residuals (CUSUM) and the CUSUM of squares (CUSUMSQ) which are given in Figure 3.
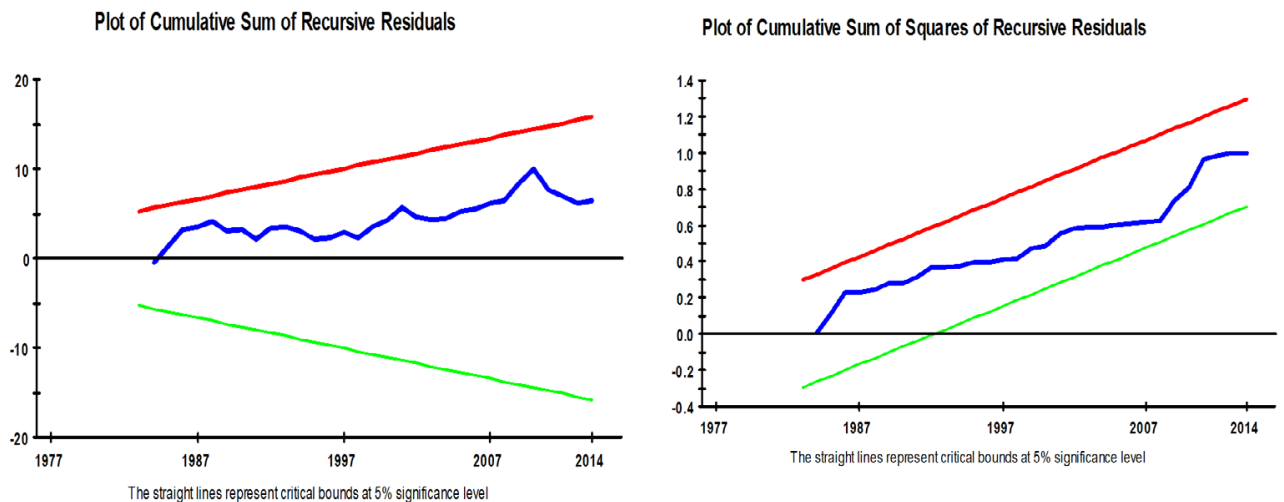

Figure 3: CUSUM and CUSUMSQ Plots

In the plots CUSUM and CUSUMSQ curves lie within the 5 percent critical bound providing evidence that the parameters of the model do not suffer from any structural instability over the period of the study and the ARDL model is not misspecified. 


\section{CONCLUSION}

This paper investigated the impact of government debt stock on the level of GDP per worker of Nepal using data of the period 1975-2014 by incorporating gross fixed capital formation (GFCF) and a measure of education-centric human capital in a Cobb-Douglas production function framework applying the ARDL approach to cointegration. The result shows that the outstanding total stock of Nepal Government's debt has no growth retarding effect; debt has positive effect on the level of per worker GDP. We rely on Keynesian proposition on the positive effect of public debt on Nepal's GDP. However this result is to be taken as indicative rather than definitive. In the face of continuously falling debt-to-GDP ratio (see Table 1 and Figure 2) the tentative suggestion of this result is that public debt in Nepal is not detrimental to the per worker GDP of the country.

The declining total-debt-to-GDP ratio arising from the falling domestic debt-to-GDP ratio and falling foreign debt-to-GDP ratio is not an alarming signal for the economy. So we conclude by saying that borrowing would be a healthy option for the government to finance its development projects to boost economic growth until the government is able to service both the domestic and foreign debt in time. Future studies should separately consider the impact of domestic debt and foreign debt on the GDP of country and attempt to approximate the optimum debt-to-GDP ratio. One more conclusion of our study is that education-centric human capital has growth accelerating effect and hence expansion of school level education should be a top priority agenda in public policy in Nepal.

\section{Annexes}

\section{Annex I: Augmented Dickey-Fuller Unit Root Test}

\section{(i) Per Worker GDP}

Null Hypothesis: $\ln Y$ has a unit root

Exogenous: Constant, Linear Trend

Lag Length: 1 (Automatic - based on SIC, maxlag=9)

\begin{tabular}{lrrr}
\hline \hline & & t-Statistic & Prob. $^{*}$ \\
\hline \hline Augmented Dickey-Fuller test statistic & -1.673417 & 0.7435 \\
\hline Test critical values: & 1\% level & -4.219126 & \\
& $5 \%$ level & -3.533083 & \\
& $10 \%$ level & -3.198312 & \\
\hline \hline
\end{tabular}

*MacKinnon (1996) one-sided p-values. 
Dependent Variable: d $(\ln Y)$

Method: Least Squares

Sample (adjusted): 19772014

Included observations: 38 after adjustments

\begin{tabular}{lrcrr}
\hline \hline Variable & Coefficient & Std. Error & t-Statistic & Prob. \\
\hline \hline $\ln Y(-1)$ & -0.096124 & 0.057442 & -1.673417 & 0.1034 \\
$\mathrm{~d}(\ln Y(-1))$ & 0.413449 & 0.148353 & 2.786932 & 0.0086 \\
$\mathrm{C}$ & 0.781648 & 0.428127 & 1.825739 & 0.0767 \\
@TREND("1975") & 0.010097 & 0.006102 & 1.654803 & 0.1072 \\
\hline \hline R-squared & 0.216251 & Mean dependent var & 0.102273 \\
Adjusted R-squared & 0.147096 & S.D. dependent var & 0.045402 \\
S.E. of regression & 0.041930 & Akaike info criterion & -3.406322 \\
Sum squared resid & 0.059777 & Schwarz criterion & -3.233945 \\
Log likelihood & 68.72013 & Hannan-Quinn criter. & -3.344992 \\
F-statistic & 3.127071 & Durbin-Watson stat & 2.200487 \\
Prob(F-statistic) & 0.038385 & & \\
\hline \hline
\end{tabular}

\section{In First Difference}

Null Hypothesis: $d(\ln Y)$ has a unit root

Exogenous: Constant

Lag Length: 0 (Automatic - based on SIC, maxlag=9)

\begin{tabular}{lccc}
\hline \hline & & t-Statistic & Prob. $^{*}$ \\
\hline \hline Augmented Dickey-Fuller test statistic & -4.230050 & 0.0019 \\
\hline Test critical values: & 1\% level & -3.615588 & \\
& $5 \%$ level & -2.941145 & \\
& $10 \%$ level & -2.609066 & \\
\hline \hline
\end{tabular}

*MacKinnon (1996) one-sided p-values.

Dependent Variable: $d(\ln Y, 2)$

Method: Least Squares

Sample (adjusted): 19772014

Included observations: 38 after adjustments

\begin{tabular}{crcrr}
\hline \hline Variable & Coefficient & Std. Error & t-Statistic & Prob. \\
\hline \hline $\mathrm{d}(\ln Y(-1))$ & -0.625267 & 0.147816 & -4.230050 & 0.0002 \\
$\mathrm{C}$ & 0.064859 & 0.016282 & 3.983401 & 0.0003 \\
\hline \hline R-squared & 0.332014 & Mean dependent var & 0.002431 \\
Adjusted R-squared & 0.313459 & S.D. dependent var & 0.051171 \\
S.E. of regression & 0.042399 & Akaike info criterion & -3.432184
\end{tabular}


Sum squared resid

0.064717 Schwarz criterion

Log likelihood

67.21150 Hannan-Quinn criter.

$-3.401519$

F-statistic

17.89332 Durbin-Watson stat

2.148773

Prob(F-statistic)

0.000153

\section{(ii) Per Worker Gross Fixed Capital Formation}

Null Hypothesis: lnGFCF has a unit root

Exogenous: Constant, Linear Trend

Lag Length: 0 (Automatic - based on SIC, maxlag=9)

\begin{tabular}{lccc}
\hline \hline & & t-Statistic & Prob. $^{*}$ \\
\hline \hline Augmented Dickey-Fuller test statistic & -5.095572 & 0.0010 \\
\hline Test critical values: & 1\% level & -4.211868 & \\
& $5 \%$ level & -3.529758 & \\
& $10 \%$ level & -3.196411 & \\
\hline \hline
\end{tabular}

*MacKinnon (1996) one-sided p-values.

Dependent Variable: d(lnGFCF)

Method: Least Squares

Sample (adjusted): 19762014

Included observations: 39 after adjustments

\begin{tabular}{lllll}
\hline \hline Variable & Coefficient & Std. Error & t-Statistic & Prob. \\
\hline \hline lnGFCF(-1) & -0.839753 & 0.164801 & -5.095572 & 0.0000 \\
C & 4.916805 & 0.952700 & 5.160916 & 0.0000 \\
@TREND("1975") & 0.090792 & 0.018668 & 4.863470 & 0.0000 \\
\hline \hline R-squared & 0.419050 & Mean dependent var & 0.114965 \\
Adjusted R-squared & 0.386775 & S.D. dependent var & 0.516236 \\
S.E. of regression & 0.404257 & Akaike info criterion & 1.100273 \\
Sum squared resid & 5.883265 & Schwarz criterion & 1.228240 \\
Log likelihood & -18.45533 & Hannan-Quinn criter. & 1.146187 \\
F-statistic & 12.98374 & Durbin-Watson stat & 2.047585 \\
Prob(F-statistic) & 0.000057 & & \\
\hline \hline
\end{tabular}

\section{In First Difference}

Null Hypothesis: d(lnGFCF) has a unit root

Exogenous: Constant

Lag Length: 0 (Automatic - based on SIC, maxlag=9)

\begin{tabular}{lcc}
\hline \hline & t-Statistic & Prob. $^{*}$ \\
\hline \hline Augmented Dickey-Fuller test statistic & -10.55350 & 0.0000 \\
\hline
\end{tabular}




\begin{tabular}{lll}
\hline Test critical values: & $1 \%$ level & -3.615588 \\
& $5 \%$ level & -2.941145 \\
& $10 \%$ level & -2.609066 \\
\hline \hline
\end{tabular}

*MacKinnon (1996) one-sided p-values.

Dependent Variable: d(lnGFCF,2)

Method: Least Squares

Sample (adjusted): 19772014

Included observations: 38 after adjustments

\begin{tabular}{lllll}
\hline \hline Variable & Coefficient & Std. Error & t-Statistic & Prob. \\
\hline \hline $\mathrm{d}(\operatorname{lnGFCF}(-1))$ & -1.511488 & 0.143221 & -10.55350 & 0.0000 \\
$\mathrm{C}$ & 0.174256 & 0.075696 & 2.302062 & 0.0272 \\
\hline \hline R-squared & 0.755728 & Mean dependent var & 0.002539 \\
Adjusted R-squared & 0.748942 & S.D. dependent var & 0.909500 \\
S.E. of regression & 0.455711 & Akaike info criterion & 1.317279 \\
Sum squared resid & 7.476204 & Schwarz criterion & 1.403468 \\
Log likelihood & -23.02831 & Hannan-Quinn criter. & 1.347945 \\
F-statistic & 111.3764 & Durbin-Watson stat & 2.314826 \\
Prob(F-statistic) & 0.000000 & & \\
\hline \hline
\end{tabular}

\section{(iii) Total Stock of Debt per Worker}

Null Hypothesis: lnTD has a unit root

Exogenous: Constant, Linear Trend

Lag Length: 0 (Automatic - based on SIC, maxlag=9)

\begin{tabular}{lccc} 
& & t-Statistic & Prob. $^{*}$ \\
\hline \hline \multicolumn{2}{l}{ Augmented Dickey-Fuller test statistic } & -0.392140 & 0.9844 \\
\hline \hline Test critical values: & 1\% level & -4.211868 & \\
& $5 \%$ level & -3.529758 & \\
& $10 \%$ level & -3.196411 & \\
\hline \hline
\end{tabular}

*MacKinnon (1996) one-sided p-values.

Dependent Variable: d(lnTD)

Method: Least Squares

Sample (adjusted): 19762014

Included observations: 39 after adjustments

\begin{tabular}{crrrr}
\hline \hline Variable & Coefficient & Std. Error & t-Statistic & Prob. \\
\hline \hline $\operatorname{lnTD}(-1)$ & -0.009064 & 0.023114 & -0.392140 & 0.6973 \\
$\mathrm{C}$ & 0.348627 & 0.133305 & 2.615254 & 0.0129 \\
@TREND("1975") & -0.006478 & 0.003574 & -1.812610 & 0.0782 \\
\hline \hline R-squared & 0.540204 & Mean dependent var & 0.141521
\end{tabular}




\begin{tabular}{lllr} 
Adjusted R-squared & 0.514660 & S.D. dependent var & 0.121191 \\
S.E. of regression & 0.084430 & Akaike info criterion & -2.031994 \\
Sum squared resid & 0.256621 & Schwarz criterion & -1.904028 \\
Log likelihood & 42.62389 & Hannan-Quinn criter. & -1.986081 \\
F-statistic & 21.14783 & Durbin-Watson stat & 1.595715 \\
Prob(F-statistic) & 0.000001 & & \\
\hline \hline
\end{tabular}

\section{In First Difference}

Null Hypothesis: $\mathrm{d}(\operatorname{lnTD})$ has a unit root

Exogenous: Constant, Linear Trend

Lag Length: 0 (Automatic - based on SIC, maxlag=9)

\begin{tabular}{lccc}
\hline \hline & & t-Statistic & Prob. $^{*}$ \\
\hline \hline Augmented Dickey-Fuller test statistic & -4.919168 & 0.0016 \\
\hline Test critical values: & 1\% level & -4.219126 & \\
& $5 \%$ level & -3.533083 & \\
& $10 \%$ level & -3.198312 & \\
\hline \hline
\end{tabular}

*MacKinnon (1996) one-sided p-values.

Dependent Variable: d $(\operatorname{lnTD}, 2)$

Method: Least Squares

Sample (adjusted): 19772014

Included observations: 38 after adjustments

\begin{tabular}{lrrrr}
\hline \hline \multicolumn{1}{c}{ Variable } & Coefficient & Std. Error & t-Statistic & Prob. \\
\hline \hline $\mathrm{d}(\operatorname{lnTD}(-1))$ & -0.809195 & 0.164498 & -4.919168 & 0.0000 \\
$\mathrm{C}$ & 0.246654 & 0.057714 & 4.273759 & 0.0001 \\
\multicolumn{1}{c}{ @TREND("1975") } & -0.006594 & 0.001773 & -3.719268 & 0.0007 \\
\hline \hline R-squared & 0.409503 & Mean dependent var & -0.006516 \\
Adjusted R-squared & 0.375760 & S.D. dependent var & 0.105645 \\
S.E. of regression & 0.083469 & Akaike info criterion & -2.053035 \\
Sum squared resid & 0.243845 & Schwarz criterion & -1.923752 \\
Log likelihood & 42.00766 & Hannan-Quinn criter. & -2.007037 \\
F-statistic & 12.13603 & Durbin-Watson stat & 2.065217 \\
Prob(F-statistic) & 0.000099 & & \\
\hline \hline
\end{tabular}

\section{(iv) Education-Centric Human Capital per Worker}

Null Hypothesis: $\ln \mathrm{H}$ has a unit root

Exogenous: Constant, Linear Trend

Lag Length: 0 (Automatic - based on SIC, maxlag=9)

t-Statistic Prob. $^{*}$




\begin{tabular}{lccc}
\hline \hline Augmented Dickey-Fuller test statistic & -1.523960 & 0.8040 \\
\hline Test critical values: & $1 \%$ level & -4.211868 & \\
& $5 \%$ level & -3.529758 & \\
& $10 \%$ level & -3.196411 & \\
\hline \hline
\end{tabular}

*MacKinnon (1996) one-sided p-values.

Dependent Variable: $\mathrm{d}(\ln \mathrm{H})$

Method: Least Squares

Sample (adjusted): 19762014

Included observations: 39 after adjustments

\begin{tabular}{lllll}
\hline \hline Variable & Coefficient & Std. Error & t-Statistic & Prob. \\
\hline \hline $\ln H(-1)$ & -0.153319 & 0.100606 & -1.523960 & 0.1363 \\
$\mathrm{C}$ & -0.698075 & 0.485636 & -1.437446 & 0.1592 \\
@TREND("1975") & 0.014384 & 0.008587 & 1.675116 & 0.1026 \\
\hline \hline R-squared & 0.074461 & Mean dependent var & 0.097589 \\
Adjusted R-squared & 0.023042 & S.D. dependent var & 0.364038 \\
S.E. of regression & 0.359820 & Akaike info criterion & 0.867376 \\
Sum squared resid & 4.660928 & Schwarz criterion & 0.995342 \\
Log likelihood & -13.91383 & Hannan-Quinn criter. & 0.913289 \\
F-statistic & 1.448126 & Durbin-Watson stat & 1.895153 \\
Prob(F-statistic) & 0.248374 & & \\
\hline \hline
\end{tabular}

\section{In First Difference}

Null Hypothesis: $d(\ln H)$ has a unit root

Exogenous: None

Lag Length: 0 (Automatic - based on SIC, maxlag=9)

\begin{tabular}{lccc}
\hline \hline & & t-Statistic & Prob. $^{*}$ \\
\hline \hline Augmented Dickey-Fuller test statistic & -5.800839 & 0.0000 \\
\hline Test critical values: & 1\% level & -2.627238 & \\
& $5 \%$ level & -1.949856 & \\
& $10 \%$ level & -1.611469 & \\
\hline \hline
\end{tabular}

*MacKinnon (1996) one-sided p-values.

Dependent Variable: d $(\ln \mathrm{H}, 2)$

Method: Least Squares

Sample (adjusted): 19772014

Included observations: 38 after adjustments

\begin{tabular}{lllll}
\hline \hline Variable & Coefficient & Std. Error & t-Statistic & Prob. \\
\hline \hline $\mathrm{d}(\ln \mathrm{H}(-1))$ & -0.952136 & 0.164138 & -5.800839 & 0.0000 \\
\hline \hline R-squared & 0.476275 & Mean dependent var & -0.002738
\end{tabular}




\begin{tabular}{llll} 
Adjusted R-squared & 0.476275 & S.D. dependent var & 0.527368 \\
S.E. of regression & 0.381650 & Akaike info criterion & 0.937339 \\
Sum squared resid & 5.389304 & Schwarz criterion & 0.980433 \\
Log likelihood & -16.80944 & Hannan-Quinn criter. & 0.952671 \\
Durbin-Watson stat & 2.002737 & & \\
\hline \hline
\end{tabular}

Source: Output of Eviews 8.

\section{Annex II}

\section{First Step Test Result of the ARDL Approach to Cointegration}

Model: $\ln Y=f(\operatorname{lnGFCF}, \operatorname{lnTD}, \operatorname{lnH}, \mathrm{C})$; Sample:1977-2014

ARDL $(1,0,0,1)$ Selected Based on Schwarz Bayesian Criterion

\begin{tabular}{lccc}
\hline Regressor & Coefficient & Standard Error & T-Ratio[Prob] \\
\hline $\ln Y(-1)$ & .78341 & .052456 & $14.9347[.000]$ \\
$\ln G F C F$ & .12119 & .050422 & $2.4035[.022]$ \\
$\ln \mathrm{TD}$ & .049063 & .014430 & $3.4001[.002]$ \\
$\ln \mathrm{H}$ & .16766 & .048592 & $3.4504[.002]$ \\
$\ln \mathrm{H}(-1)$ & -.12915 & .049558 & $-2.6060[.014]$ \\
Intercept & .89500 & .16127 & $5.5498[.000]$ \\
\hline
\end{tabular}

R-Squared=.99925; R-Bar-Squared =.99914; S.E. of Regression=.034751;F-Stat. F $(5,32)=8566.0$ [.000]; Mean of Dependent Variable $=9.7528$; S.D.of Dependent Variable $=1.1828$; Residual Sum of Squares $=.038643 ;$ Equation Log-likelihood $=77.0087$; Akaike Info . Criterion $=71.0087$; Schwarz Bayesian Criterion=66.0960;DW-statistic $=1.8139 ; \quad$ Durbin's h-statistic $=.60604[.544]$

\begin{tabular}{ccccc}
\hline \multicolumn{3}{c}{ Testing for existence of a level relationship among the variables in the ARDL model } \\
\cline { 2 - 5 } Computed F & \multicolumn{3}{c}{$95 \%$} & \multicolumn{3}{c}{$90 \%$} \\
5.0922 & Lower bound & Upper bound & Lower bound & Upper bound \\
\cline { 2 - 5 } & 3.5601 & 4.8365 & 2.9234 & 4.0364 \\
\hline
\end{tabular}

Source: Output of Microfit 5, estimated by the author.

\section{References}

Akinboade, O. A., Ziramba, E., \& Kumo, W.L. (2008). The demand for gasoline in South Africa: An empirical analysis using cointegration technique. Energy Economics, 30, 3222-3229.

Bahamani-Oskooee, M., \& Ardalani, Z. (2006). Exchange rate sensitivity of U.S. trade flows: Evidence from industry data. Southern Economic Journal, 72, 542-559. 
Bardsen, G. (1989). Estimation of long run coefficients in error correction models. Oxford Bulletin of Economics and Statistics, 51, 345-350.

Baldacci, E., \& Kumar, M.S. (2010). Fiscal deficits, public debt and sovereign bond yields. IMF Working Paper WP/10/184.Washington, DC: International Monetary Fund.

Banerjee, A., Dolado, J., \& Mestre, R. (1998). Error correction mechanism tests for cointegration in a single equation framework. Journal of Time Series Analysis, 19, 267-283.

Banerjee, A., Dolado, J., Galbraith, J.W., \& Hendry, D.F. (1993). Co-integration, error correction and the econometric analysis of non-stationary data. Oxford: Oxford University Press.

Barro, R.J. (1979). On the determinants of public debt. Journal of Political Economy, 85,940-971.

Barro, R. J. (1989).The Ricardian approach to budget deficits. The Journal of Economic Perspectives, 3(2), 37-54.

Barro, R.J. (1995). Inflation and economic growth. NBER Working Paper No.5326. Cambridge, Massachusetts: National Bureau of Economic Research.

Baumol, W. J., \& Maurice, H. P. (1955). More on the multiplier effect of a balanced budget. The American Economic Review, 45,140-148.

Benhabib, J., \& Spiegel, M. (1994). The role of human capital in economic development: Evidence from aggregate cross-country data. Journal of Monetary Economics, 34, 143-173.

Burnside, C., Eichenbaum, M. \& Rebelo, S.(2001).Prospective deficits and the Asian currency crisis. Journal of Political Economy, 109, 1155-1197.

Cochrane, J.H.(2011). Understanding policy in the great recession: Some unpleasant fiscal arithmetic. European Economic Review, 55(1), 2-30.

Cordella, T., Ricci, L.A., \& Ruiz-Arranz, M. (2010).Debt overhang or debt irrelevance. IMF Staff Papers,57(1),1-24.

Diamond, P. (1965). National debt in a neoclassical growth model. The American Economic Review, 55, 1126-1150.

Dickey, D. A., \& Fuller, W. A. (1979). Distribution of the estimators for autoregressive time series with a unit root. Journal of the American Statistical Association, 74, 427-431. 
Dickey, D. A., \& Fuller, W. A. (1981). Likelihood ratio statistics for autoregressive time series with a unit root. Econometrica, 49, 1057-1072.

Dotsey, M. (1994).Some unpleasant supply side arithmetic. Journal of Monetary Economics, 33, 507-524.

Elmendorf, D.W. \& Mankiw, N.G. (1999). Government Debt. In J.B. Taylor and M. Woodford (Eds.). Handbook of macroeconomics Vol.1C. (pp.1615 - 1669). Amsterdam, North-Holland: Elsevier Science B.V.

Engle, R. F., \& Granger, C.W. (1987). Cointegration and error correction: Representation, estimation, and testing. Econometrica, 55, 251-267.

Gale, W., \& Orzag, P. (2003). The economic effects of long-term fiscal discipline (Discussion Paper No.8).Urban-Brookings Tax Policy Center. Washington, DC: The Urban Institute.

Harris, R., \& Sollis, R. (2003). Applied time series modelling and forecasting. West Sussex, England: John Wiley \& Sons Ltd.

Haavelmo, T. (1945). Multiplier effects of a balanced budget. Econometrica, 13, 311318.

Hemming, R., Kell, M. \& Schimmelpfennig, A. (2003).Fiscal vulnerability and financial crises in emerging market economies (IMF Occasional Paper No.218). Washington, DC: International Monetary Fund.

Johansen, S. (1988). Statistical analysis of cointegration vectors. Journal of Economic Dynamics and Control 12, 231-254.

Johansen, S. (1991). Estimation and hypothesis testing of cointegration vectors in Gaussian vector autoregressive models. Econometrica, 59, 1551-1580.

Johansen, S. \& Juselius, K. (1990). Maximum likelihood estimation and inferences on cointegration with applications to the demand for money. Oxford Bulletin of Economics and Statistics, 52, 169-210.

Johnston, H.G.(1969).Inside money, outside money, income, wealth, and welfare in monetary theory. Journal of Money Credit, and Banking, 1, 30-45.

Kremers, J. J. M., Ericsson, N. R., \& Dolado, J. J. (1992). The power of cointegration tests. Oxford Bulletin of Economics and Statistics, 54, 325-348.

Kumar, M.S., \& Woo, J. (2010). Public debt and growth (IMF Working Paper WP/10/174). Washington, DC: International Monetary Fund.

Laurenceson, J., \& Chai, J.C.H. (2003). Financial reform and economic development in China. Cheltenham, UK: Edward Elgar. 
Levhari, D., \& Patinkin, D. (1968).The role of money in a simple growth model. American Economic Review, 58, 713-753.

Liang, Q., \& Cao, H. (2007). Property prices and bank lending in China. Journal of Asian Economics, 18, 63-75.

Lucas, R.E., Jr. (1988). On the mechanics of economic growth. Journal of Monetary Economics, 3, 3-42.

Mankiw, N.G., Romer, D., \& Weil, D. (1992). A contribution to the empirics of economic growth. Quarterly Journal of Economics, 57, 407-437.

Modigliani, F.(1961). Long-run implications of alternative fiscal policies and the burden of the national debt. Economic Journal, 71, 730-755.

Nadiri, M.I. (1969). The determinants of real cash balances in the US manufacturing. Quarterly Journal of Economics, 83, 173-196.

Narayan, P.K., \& Smyth, R. (2005). Trade liberalization and economic growth in Fiji. An empirical assessment using the ARDL approach. Journal of the Asia Pacific Economy, 10 (1), 96 -115.

Nelson, R.R., \& Phelps, E. (1966). Investment in humans, technology diffusion, and economic growth. American Economic Review, 56, 69-75.

Nepal Rastra Bank. (2010). A handbook of government finance statistics Vol.III. Baluwatar, Kathmandu: Author.

Odhiambo, N.M. (2009). Energy consumption and economic growth nexus in Tanzania: An ARDL bounds testing approach. Energy Policy, 37, 617-622.

Ouattara, B. (2004). Modelling the long run determinants of private investment in Senegal (CREDIT Research Paper No 04/05). Centre for research in Economic Development and International Trade, University of Nottingham. Retrieved on April, 20, 2013, from, http://www.nottingham.ac.uk/credit/documents/ papers/04-05.pdf

Pahlavani, M., Wilson, E., \& Worthington, A.C. (2005). Trade-GDP nexus in Iran: An application of the autoregressive distributed lag (ARDL) model. American Journal of Applied Sciences, 2, 1158-1165. doi:10.3844/ajasso.2005.1158.1165.

Panizza, U., \& Presbitero, A.F.(2013).Public debt and economic growth in advanced economies: A survey. Swiss Journal of Economics and Statistics, 149(2), 175-204.

Pattichis, C.A. (1999). Price and income elasticities of disaggregated import demands: Results from UECMs and an application. Applied Economics, 31, 1061-1071. 
Pattillo, C., Poirson, H., \& Ricci, L.A. (2011).External debt and growth. Review of Economics and Institutions, 2(3), 30. doi: http://dx.doi.org/10.5202/rei.v2i3.45

Pesaran, M.H. \& Shin, Y. (1997). An autoregressive distributed lag modelling approach to cointegration analysis (This is a revised version of a paper presented at the Symposium at the Centennial of Ragnar Frisch, The Norwegian Academy of Science and Letters, Oslo, March 3-5, 1995). Retrieved on March 30, 2013, from $\mathrm{http} / / / w w w . g o o g l e . c o m . n p / u r l ? \mathrm{sa}=\mathrm{t}$ andrct=j andq= andesrc $=\mathrm{s}$ andsource=web andcd $=1$ andved=0CDMQFjAA andurl=http $\% 3 \mathrm{~A} \% 2 \mathrm{~F} \% 2 \mathrm{Fciteseerx}$.ist.psu.e du\%2Fviewdoc\%2Fdownload\%3Fdoi\%3D10.1.1.153.3246\%26rep\%3Drep1 \%26type\%3Dpdf andei=oAtWUZSfD4eQrgeLloGYCg andusg=AFQjCNH2FMUeb_0oeztx4mpMCMNDMyIUQ andbvm=bv.44442042,d.bmk

Pesaran, M.H. \& Smith, R. (1998). Structural analysis of cointegration VARs. Journal of Economic Surveys, 12,471-505.

Pesaran, M.H., Shin, Y. \& Smith, R. (2001). Bounds testing approaches to the analysis of level relationships. Journal of Applied Econometrics, 16, 289-326.

Presbitero, A. (2012). Total public debt and growth in developing countries. The European Journal of Development Research, 24, 606-626.

Rehman, H. Ur \& Afzal, M. (2003). The J-curve phenomenon: An evidence from Pakistan. Pakistan Economic and Social Review, 41(1/2), 45-58.

Reinhart, C. \& Rogoff, K. (2010).Growth in a time of debt. The American Economic Review, 100, 573-578.

Romer, P. (1986). Increasing returns and long-run growth. Journal of Political Economy, 94, 1002-1037.

Romer, P. M. (1990a). Human capital and growth: Theory and evidence. CarnegieRochester Conference Series on Public Policy, 32, 251-286.

Romer, P.M. (1990b). Endogenous technological change. Journal of Political Economy, 98 (Part II), S71-S102.

Saint-Paul, G. (1992).Fiscal policy in an endogenous growth model. Quarterly Journal of Economics, 107, 1243-1257.

Sargent, T., \& Wallace, N.(1981).Some unpleasant monetarist arithmetic. Federal Reserve Bank of Minneapolis Quarterly Review (Fall),5, 1-17.

Seetanah, B. (2008). Financial development and economic growth: An ARDL approach for the Case of the small island state of Mauritius. Applied Economics Letters, 15, 809-813. http://dx.doi.org/10.1080/13504850600770889

Sezgin, S. \& Yildirim, T. (2002). The demand for Turkish defense expenditure. Defence and Peace Economics, 13(2), 121-128. 
Shrestha, M. (2005). Financial liberalization in Nepal (Doctoral dissertation).School of Economics and Information, University of Wollongong, Australia. Retrieved on April 24, 2013, from http://ro.uow.edu.au/cgi/viewcontent.cgi?filename=0 andarticle $=1308$ and context=theses andtype $=$ additional

Stock, J.H., \& Watson, M.W.(2006). Introduction to econometrics (2nd ed.). Boston: Pearson Addison Wesley.

Stock, J.H., \& Watson, M.W. (1988).Testing for common trends. Journal of the American Statistical Association, 83, 1097-1107.

Studenmund, A.H. (2000). Using econometrics: A practical guide (4th ed.). Reading, MA: Addison Wesley Longman.

Uzawa, H. (1965). Optimal technical change in an aggregative model of economic growth. International Economic Review, 6 (1), 18-31.

Verma, R. (2007). Savings, investment and growth in India: An application of the ARDL bounds testing approach. South Asia Economic Journal, 8(1), 87-98.

Woo, J. (2009).Why do more polarized countries run more procyclical fiscal policy? Review of Economics and Statistics, 81, 850-870. 